\title{
Adult Education, Social Transformation and the Pursuit of Social Justice
}

\section{Alan Tuckett}

At first sight, adult education lacks capacity to contribute significantly to social transformation for social justice. Except perhaps in the Nordic countries, adult education sits, overwhelmingly, at the margins of public educational systems with limited budgets, modest levels of professional staffing, and, at best, variable facilities. The 2015 Education For All Global Monitoring Report (GMR) reports that 'adult education in high income countries appears to have mostly served those who completed secondary education rather than adults who lack basic skills' (UNESCO, 2015, p. 109; OECD, 2013). It states that, after 25 years of global targets giving priority to reducing illiteracy, 781 million adults still lack literacy, and, of them, 64\% are women, a percentage that has remained unchanged since 1990; and that ethnic and linguistic minorities, disabled adults, rural and indigenous communities benefit little from programmes. It also finds that such literacy gain as there has been in most countries can be explained by cohort change - better-schooled young people displacing lessskilled older adults in the population (UNESCO, 2015). To borrow a memorable phrase of Helena Kennedy, it seems that 'If at first you don't succeed, you don't succeed' (FEFC, 1997).

Yet, despite this evidence, adult educators overwhelmingly see their role as facilitators of social transformation. Recognising that people who enjoyed education early in their lives are more likely to readily come back for more than those who had negative experiences of schooling or none at all, adult educators ask 'who isn't there, and what can be done about it?', and, as a result, develop programmes that target under-represented and marginalised groups and design programmes starting from learners' experiences, backed by effective outreach programmes. They see their role as supporting adults through a process best described by the Welsh European cultural critic and adult educator, Raymond Williams (Williams, 1983). He argued that at times of change people turned to learning in order to understand what was going on, to adapt to it, and most importantly to shape change. It is work that can secure change at the level of individuals, communities, and less often, nations.

Perhaps the most celebrated evidence of a national impact comes from 19th century Denmark, where Grundtvig's influence in developing Folk High Schools based on dialogue and co-operative learning led the country's farmers, faced with bankruptcy, to learn their way out of their difficulties by recognising the strength of working and trading co-operatively (Korsgaard, 2014). The Danish experience influenced the evolution of the 'study circle democracies' across Scandinavia and had the indirect effect of contributing to the creation of some of the least unequal societies in the world (UNDP, 2014; Wilkinson \& Pickett, 2009). Action developed in voluntary adult education, made use of by social movements, was then adopted by the State.

It is impossible to read the history of the civil rights movement in the US without recognising the seminal influence of Highlander Folk High School in forging strategies for non-violent direct action in seminars that involved Rosa Parks and Martin Luther King. The 
centre, founded by Myles Horton and Don West to parallel the Danish, saw the role of adult education as providing a site for reflection, analysis and strategising for action to secure social justice, and that it needed to be firmly aligned to wider social movements, such as the NAACP or the trade union movement. It was anything but neutral (Horton, 1998).

In 1997, when introducing a fresh commitment to adult education for social change as state policy in England, David Blunkett, the Secretary of State for Education and Employment, recognised explicitly that most efforts for social transformation had initiated not with the State, but from community self-help. He argued:

We are fortunate in this country to have a great tradition of learning. We have inherited the legacy of the great self-help movements of the Victorian industrial communities. Men and women, frequently living in desperate poverty, were determined to improve themselves and their families. They did so through the creation of libraries, study at workers' institutes, through the pioneering efforts of the early trade unions, at evening classes, through public lectures and correspondence courses. Learning enriched their lives, and they, in turn, enriched the whole of society (DfEE,1997,p. 3).

Slowly but surely, that creative self-help and structured adult learning led to the establishment of publicly-funded institutions. However, Blunkett might have gone on to say that state policy interventions were vulnerable to sudden changes of focus and commitment. Certainly, the inspiring programmes for lifelong learning he instigated lasted at most two years after his period of office, as a narrower utilitarian conception of the role of lifelong learning was imposed.

Nor was the work of Paulo Freire $(1970,1972)$ whose writing had a major influence on my generation of adult educators. The focus of his work was on literacy, recognising that it is fundamental to autonomous social action and the exercise of full citizenship. His analysis that education is never neutral, that it either domesticates or liberates, that literacy was about reading the world rather than just decoding words, and that the role of teachers is to facilitate a democratic dialogue for learning struck a chord with educators across the world. Of course, the evidence from Brazil under the dictators, where the success of Freire's methods in mobilising wider social action led to the programmes being closed and books burned, was a sober reminder that education by itself is insufficient for securing short term political change. Nevertheless, the influence of Freire's analysis, for example through Action Aid's REFLECT programme, has shaped developments that have reduced the level of marginalisation of millions of learners.

Social change flows, too, from the emergence of ideas and analysis embodied in social movements, and adult education, with its democratic and dialogical forms, can provide a test bed for the exploration of thinking. In Britain, for example, adult education played just such a role in the emergence and development of second-wave feminism, offering safe places for women who were not ready to go to women's movement consciousness-raising groups to put their toes in the water and explore what the ferment of feminist debate meant for them. At 
the same time, women's studies courses in adult education explored the roles of women in history, art and architecture, politics, business and industry. As the ideas became more mainstream, they moved into universities and more formal educational structures.

The pursuit of social justice relies not only on progressive change, but on securing rights already gained. In Haiti, following its catastrophic earthquake, and with civil administration collapsed, survivors already facing the loss of family members and of their housing were confronted with developers' plans, backed by donor finance, to take over and rebuild on their land. The voluntary organisation Defenders of the Oppressed developed a rapid adult education training programme for barefoot legal aid workers to defend the land claims of earthquake victims. At best, of course, the outcome was to sustain people's rights to their land - and to be compensated properly for relocation. This might be best seen as adult education and community action to sustain and defend rather than transform lives. Indeed, as Schuller and colleagues argue, sustaining autonomous lives is as important a function of adult learning as transforming them (Schuller et al, 2004).

If civil society is often the source of innovation, government action can make a real difference. The national literacy campaign of Nepal has secured substantial literacy gains for its population through a strategy built on partnership and the recognition of the importance of promotion, as Vishnu Karki observed:

The mobilization and recruitment of learners through awareness campaigns is crucial for the success of all large scale literacy programs. Most of Nepal's literacy graduates encouraged others to participate in literacy classes (OECD, 2015, p. 137).

But as the experience of Nirantar, a feminist literacy NGO working in Uttar Pradesh in India demonstrates, enlightened government action is not often of itself enough. Indian legislation guarantees women the right to education, but for Dalit (untouchable) women in the Lalitpur district, social norms made accessing that right impossible without Nirantar's combination of education and social action. This has without doubt transformed the lives of Dalit women, who have moved from learners to teachers, to district organisers, and have developed programmes from literacy to civic education designed to secure women's representation in political and civic leadership.

As Karki identifies, motivation is of key importance in engaging under-represented adults. The growth of Adult Learners' Weeks and their spread across the world is grounded in celebrating existing learners in all their variety in order to persuade others to join in and overcome the sense that participation 'is not for the likes of us'. By involving broadcast media, businesses, social partners, and by creating festivals of learning which combine aspects of theatre or circus with advice services and taster courses, they reach beyond conventional educational structures (Bochynek, 2002; Tuckett, 2008). They also generate powerful stories of social change and transformation, albeit at a more modest level. There is evidence aplenty of transformation, as the Adult Learners' Week winner in the UK, 'School of Fish' demonstrates. Anne Wallace is the proprietor of a struggling fish and chip shop in a shopping precinct in a depressed area of Stockport. She recognised that her firm's survival 
depended on the regeneration of the precinct, mortgaged her house, opened a community drop-in centre next door to her café, put in computers, offered coffee, and in response to demand offered classes, subsequently drawing on public funding from the UK and from the European Social Fund. The transformation of the area was dramatic, hundreds learned through the School of Fish, empty boarded properties were re-let and a dying community recovered a sense of energy resulting from users recognising their own agency and the strength of collective action (NIACE, 2012). Learning of that sort leaks: what you learn in one context can be rapidly applied elsewhere.

There is no doubt that through innovative provision, strategies to motivate and engage learners and alliances with government and other social actors, adult education can make a difference. Nevertheless, despite this, overall, its marginalisation is increasing and its budgets reducing in most countries of the world.

Yet, when in September, the United Nations signs up to a suite of development goals aimed at the eradication of poverty for the years 2015 to 2030, there is scarcely one that can be achieved without adults understanding, adapting behaviour and owning the challenges - in short learning. Measures to contain and eradicate HIV/Aids can only succeed if people understand the causes and adapt their behaviour in the light of what they learn. Clean water and sanitation are not just a technical issue, but involve people learning the risks associated with using polluted water. Maternal and early childhood mortality rates involve a combination of medical and public health issues. Gender equality involves learning how rights can be asserted and existing power structures changed. And to address the challenges of climate change and the need to live sustainably we all need to learn how to live differently.

All in all, then, adult learning is a necessary but not sufficient component in social change, and where the formal structures of adult education can engage with external social forces it can play a constructive and dynamic role. Perhaps alongside its task in offering second chances that do transform the lives of individual learners and groups of users, its most important current task is to share in securing the public space for the debate of alternatives to the neo-liberal consensus that increase inequality and reinforce marginalisation. There are few metrics that can capture the importance or the impact of that work, but as Einstein remarked, not everything worth counting can be counted.

Alan Tuckett, University of Wolverhampton, Wulfruna Street, Wolverhampton, WW1 1LY, $U K$.

Email: alan.tuckett@gmail.com

Website: www.wlv.ac.uk/research/alan-tuckett

\section{REFERENCES}

BLUNKETT, D. (1997) 'Foreword' in: DfEE, The Learning Age (London, HMSO).

BOCHYNEK, B. (2002) International adult learners' week, Convergence, 35, pp 11-26. 
FREIRE, P. (1970) Pedagogy of the Oppressed (New York, Herder and Herder).

FREIRE, P. (1972) Cultural Action for Freedom (Harmondsworth, Penguin).

HORTON, M. (1998) The Long Haul: an autobiography (New York, Teachers College Press).

KORSGAARD, O. (2011) Grundtvig's philosophy of enlightenment and education, in: E. BROADBRIDGE, C. WARREN \& U. JONAS (Eds) The School for Life: N.F.S. Grundtvig on education for the people (Aarhus, Aarhus University Press).

NIACE (2012) Adult Learners' Week Winners' Booklet (Leicester, NIACE).

SCHULlER, T., PRESTON, J., HAMMOND, C., BRASSETT-GRUNDY, A., \& BYNNER, J. (2004) The Benefits of Learning: the impact of education on health, family life and social capital (London, Routledge).

TUCKETT, A. (2008) Making the case for adult learning: the role of non-governmental organisations and networks, in: P. Jarvis (Ed) The Routledge International Handbook of Lifelong Learning (pp 323-331) (London, Routledge).

UNDP (2014) Human Development Report 2014: sustaining human progress, reducing vulnerabilities and building resilience (New York, UNDP).

UNESCO (2015) Education for all 2000-2015: achievements and challenges, (The EFA Global Monitoring Report 2015), Paris,

UNESCO (2008) Making the case for adult learning: the role of non-governmental organisations and networks, in: P. JARVIS (Ed) The Routledge International Handbook of Lifelong Learning, pp 323-331

WILKINSON, R., \& PICKETT, K. (2009) The Spirit Level: why more equal societies almost always do better (London, Allen Lane).

WILLIAMS, R. (1983) Adult education and social change, in Lectures and reminiscences in honour of Tony McLean (Southampton, WEA Southern District). 